\title{
Share repurchase and dividend payout behaviour: The South African experience
}

\author{
N. Wesson ${ }^{a \star}$, B.W. Bruwer ${ }^{\mathrm{b}}$ and W.D. Hamman ${ }^{\mathrm{a}}$ \\ ${ }^{a}$ University of Stellenbosch Business School, South Africa \\ bUniversity of Stellenbosch School of Accounting, South Africa \\ *To whom all correspondence should be addressed \\ nicolene.wesson@usb.ac.za
}

\begin{abstract}
Share repurchases, rather than dividend payments, are increasingly becoming the globally favoured payout method. This has prompted a renewed interest in the field, and raises questions about the actual motivation for share repurchases and whether companies are now repurchasing shares in preference to investing in future growth. This study set out to ascertain whether South African company payout behaviour mirrors global company behaviour. Comprehensive data on share repurchases are, however, not compiled by South African financial data sources or by the Johannesburg Stock Exchange Ltd. In preparation for this study, the authors thus compiled the first comprehensive share repurchase database for companies in selected JSE-listed sectors for the first 11 years (i.e. 1999 to 2009) since share repurchases were first allowed in this country.
\end{abstract}

Share repurchases were found to be a popular payout method, especially in the more recent periods covered in the study. Payout value was dominated by a few companies paying dividends every year and regularly repurchasing shares. Aspects unique to the South African regulatory environment, however, resulted in the South African share repurchase experience not fully mirroring current global practice. The main constraint in the South African share repurchase environment is that comprehensive, actual-time-based share repurchase data are not available. Recommendations are made on how to align the South African regulatory environment with global best practice. Regulatory changes, as well as continued research in the field, will equip stakeholders to make informed decisions.

This work is based upon research supported by the National Research Foundation. All opinions, findings, conclusions and recommendations expressed in this material are those of the authors and the NRF does not accept any liability in this regard.

\section{Introduction}

The amounts spent on share repurchases have increased dramatically over the last decade. Empirical evidence on the motivation for share repurchases generally shows that share repurchase announcements are accompanied by positive announcement returns, and that these returns are more evident over three to four years (Ikenberry, Lakonishok \& Vermaelen, 1995). An increase in the share price subsequent to a share repurchase announcement (accompanied by a reduction in the number of shares) benefits not only the remaining shareholders, but also executives when their remuneration is linked to share price and earnings per share (EPS) performance. The large amounts spent on share repurchases are now raising concerns about whether companies are utilising cash resources wisely and whether future growth and job creation are still a priority when deciding on utilising excess cash (Lazonick, 2014).

In most jurisdictions the share repurchase concept is an established practice. Share repurchase data are readily available in most countries, because most global security exchanges require share repurchase announcements to be made on a regular and actual-time basis. Considerable research in the field already exists, providing empirical evidence on the extent of share repurchases and motivations for share repurchases. The highest value of share repurchases occurs in the United States of America (USA), where share repurchases have been allowed for the past four decades, but only became popular in the 1980s and accelerated in the 1990s (Dittmar, 2008: 27). In the USA share repurchases will top the one trillion mark for the first time in 2015 and have, since 2005, exceeded dividend payouts (Barnes, 2015; Dittmar, 2008). The value of share repurchases in the USA exceeded the value of new shares issued since 2000, and in 2014 exceeded the value of new shares issued by five times (Barnes, 2015; Brennan, 2007: 2). The United Kingdom (UK), where share repurchases were legalised in 1981, shows the next highest growth in share repurchase value (Kim, Schremper \& Varaiya, 2004: 5). Most other jurisdictions allowed share repurchases only in the 1990s.

Share repurchases were allowed in South Africa as from 1 July 1999. The South African regulatory environment, however, differs from most other jurisdictions in respect of the announcement requirements for share repurchases. In South Africa open market share repurchases need to be announced only via the Security Exchange News Service (SENS) once a cumulative three per cent limit has been reached, which results in announced share repurchases not 
reflecting comprehensive nor actual-time-based data. In an exploratory study by Bester, Wesson and Hamman (2010) it was found that there are, apart from the three per cent announcement rule on open market share repurchases, also other aspects unique to the South African regulatory environment, namely the non-cancellation of own shares repurchased; the allowing of subsidiaries to hold up to 10 per cent of the holding company's shares; the tax treatment of share repurchases; and the inconsistent application of the regulatory requirements by the JSE-listed companies in their annual reports and SENS announcements.

Comprehensive share repurchase data are not recorded by South African financial data sources or by the Johannesburg Stock Exchange Ltd (JSE). The full extent of share repurchases by JSE-listed companies is therefore not generally known.

In the study reported in this article, comprehensive data on share repurchases and dividend payments for companies in selected JSE-listed sectors, for the period 1999 to 2009, were compiled by using annual reports as the primary source of data. There was an expectation that South Africa, being a developing country and an emerging economy, would not necessarily mirror the global precedent set by developed countries. The exposure of data on share repurchases and dividends would help to determine whether the South African share repurchase experience mirrors global practice and whether current theoretical thinking on the motivation for share repurchases also applies in this country. This study analysed the share repurchase and dividend data to determine the payout behaviour in South Africa during the first 11 years since share repurchases were allowed. An assessment was made on whether the South African regulatory environment adequately addresses the share repurchase payout option available to companies. The results of this study will equip stakeholders with a better understanding of the popularity of share repurchases and whether this payout method deserves the same attention in South Africa as it presently receives globally.

The following sections provide a theoretical framework on share repurchase and dividend payout behaviour, and cover the population and methodology of the study, the results and a discussion thereof, and close with concluding remarks.

\section{Theoretical framework}

When a company has excess capital resources, it has two alternatives: to invest the funds to advance business goals or to return the cash to claim holders through dividends, debt repayments or share repurchases. Global empirical evidence exists on the extent of share repurchases and dividend payments, and the interaction between these two payout methods. In this theoretical framework the South African share repurchase and dividend payout behaviour is compared with global practice.

\section{Share repurchases}

Although there are regulatory differences between countries, certain concepts and practices relating to share repurchases apply in most countries. Similar share repurchase types generally apply in most countries. Regulatory differences do occur in respect of the level of authorisation required to repurchase shares; the type of entities which may repurchase shares in the holding company; the announcement rules on share repurchase activities; and whether shares repurchased are treated as treasury shares.

There are essentially three types of share repurchases. The first share repurchase type entails the holding company repurchasing its own shares in the open market at the prevailing market price and is generally referred to as an open market share repurchase. The second type of share repurchase is generally referred to as a tender offer and is usually made to existing shareholders on a pro rata basis. The third type of share repurchase is generally referred to as a private offer and is targeted at a specific group of shareholders. There are more requirements to be adhered to (e.g. regarding establishing the purchase price, shareholder notification and/or approval prior to the share repurchase being made, etc.) in respect of tender offers and private offers, as opposed to open market share repurchases. Open market share repurchases are therefore seen as a more flexible payout method. Globally the open market share repurchase type is the most popular share repurchase method. About 90 per cent of share repurchase value in the USA was completed through the open market between 1984 and 2000 (Grullon \& Michaely, 2004: 651; Ikenberry et al., 1995: 182). In 1997 open market share repurchases amounted to between 90 and 95 per cent of European share repurchase value (Fairchild \& Zhang, 2005).

The level of authorisation for share repurchases differs between countries: in some jurisdictions (e.g. Australia, Canada, India, Israel, New Zealand, Switzerland, Taiwan, Thailand and the USA) only board approval is required; while most countries require shareholder approval (Manconi, Peyer $\&$ Vermaelen, 2013). The shareholder approval on open market share repurchases often simply reflects a routine request at the shareholder meeting to allow management to repurchase shares in the open market at a future date, if and when they deem fit. The shareholder approval on tender offers and private offers, on the other hand, generally represents a binding commitment for management to repurchase the shares from the shareholders willing to sell.

Shares are generally only repurchased by the holding company. Generally these repurchased shares are not cancelled from issued share capital, but are held in treasury (and called treasury shares) and remain available for resale (and may for example be transferred to beneficiaries under a share incentive scheme). In the USA the holding company, as well as its subsidiaries (provided that certain restrictive measures are adhered to), may repurchase shares in the holding company and these repurchased shares (by the holding company as well as by subsidiaries) are treated as treasury shares. Some countries (e.g. Australia and Canada) 
allow shares to be repurchased only by the holding company, but these repurchased shares are then cancelled from the issued share capital (and in Australia they are also cancelled from authorised capital) - and hence the treasury share principle does not apply in these countries. (Cassim, 2003: $144-145,151)$

Most global exchanges require companies to announce their share repurchases immediately after repurchases have been implemented - either on the day subsequent to the announcement (in the case of the UK, Hong Kong, Canada and Australia), a week subsequent to the repurchase (in the case of France) or at the end of the quarter (in the case of the USA) (Ginglinger \& Hamon, 2007: 919; Kobokoane, 2007: 16-17; Mitchell \& Dharmawan, 2007: 149). In the USA there was no formal requirement to announce share repurchases prior to 2004. However, since 2004 USA companies have had to announce share repurchases on a quarterly basis (disclosing figures for each month). Prior to 2004 USA companies usually only announced their intention to repurchase in the financial media.

The main differences between the South African regulatory environment and the global share repurchase scene are in respect of the announcement structure, the types of entities which may repurchase shares in the holding company and the classification of treasury shares. Regarding the share repurchase types and authorisation for share repurchases, the South African share repurchase environment is comparable to the practices followed in most countries.

South African legislation (RSA, 1999) uses the terms "general repurchases" when referring to open market share repurchases and "specific repurchases" when referring to tender offers and private offers. In terms of the JSE Listings Requirements (JSE, 2007), the specific repurchase type is divided into two categories: pro rata offers and other specific offers (the latter are similar in type to the global private offer). During the period covered in this study (i.e. 1999 to 2009), share repurchases by South African companies required shareholder approval. Although the New Companies Act of 2008 (RSA, 2008), effective from 1 May 2011, requires only board approval for share repurchases, this requirement is not applicable to JSE-listed companies as the JSE Listings Requirements still stipulate that shareholder approval should be obtained in most instances (JSE, 2013).

In South Africa the entities which may repurchase shares in the holding company are: the holding company itself, its subsidiaries (up to a limit of 10 per cent of the issued shares of the holding company) and its share trusts (RSA, 1999). Shares repurchased by the holding company are cancelled from the issued share capital and shares repurchased by subsidiaries, as well as consolidated share trusts, are treated as treasury shares and hence not cancelled from issued share capital (RSA, 1999). The fact that South African share repurchases by the holding company are cancelled from issued share capital, as well as that subsidiaries (and share trusts) are allowed to repurchase shares in the holding company, complicates the disclosure of share repurchases in the annual reports of South African companies. South Africa applies International Financial Reporting Standards (IFRS), which are promulgated in the UK. The UK regulatory environment treats the shares repurchased by the holding company as treasury shares, and does not allow subsidiaries (and share trusts) to repurchase shares in the holding company. These regulatory differences lead to inconsistent disclosures on share repurchases in the annual reports of South African companies (Wesson \& Hamman, 2011; Wesson \& Hamman, 2013).

Specific share repurchases should be announced on SENS once the terms of the repurchase have been agreed upon, while general (or open market) share repurchases should be announced in SENS once the company has cumulatively acquired three per cent of its initial number of issued shares (of that class, as at the date of the resolution). Share repurchases by share trusts, however, are not required to be announced via SENS (JSE, 2007). While the official stance of the JSE is that the three per cent announcement rule is not limited to a specific year, it appears that JSE sponsors have advised their clients that the three per cent threshold runs from one annual general meeting, when the authorisation is granted, to the next (Crotty, 2012). Announcements of open market share repurchases may therefore refer to share repurchases made in the previous year(s)/month(s)/week(s) and on the previous day, depending on how the rule is interpreted and when the limit is reached. The three per cent announcement rule on open market share repurchases results in SENS announcements not reflecting comprehensive share repurchase activity by JSE-listed companies.

Tax implications may affect the decision to enter into a share repurchase or dividend payment transaction. Globally share repurchases and dividends are generally taxed in the hands of the shareholders (and capital gains tax, income tax and/or a withholding tax on dividends are applicable). During the period covered in this study (i.e. 1999 to 2009) the income tax consequences for share repurchases and dividend payments in the South African regulatory environment differed from global practice. The tax implications for share repurchases and dividend payments by South African companies were generally similar: secondary tax on companies (STC) was levied on the distribution made (excluding the repayment of share capital and capitalised profits). There was, however, no STC levied on share repurchases made by subsidiaries. Specific requirements were also applicable when the holding company repurchased treasury shares held by subsidiaries: essentially there was a STC-free period prior to 1 October 2007 and a STC-payable period as from 1 October 2007 (Wesson \& Hamman, 2012). The tax treatment of share repurchases by subsidiaries and the subsequent sale of treasury shares to the holding company could therefore have affected the share repurchase activity during the period covered in the study. The South African STC legislation was replaced with a withholding tax system as from 1 April 2012, which is in line with current global practice.

The unique South African regulatory requirements pertaining to shares repurchased by subsidiaries and the subsequent sale thereof to the holding company affect the classification of 
specific share repurchases in the South African regulatory environment, as well as the types of entities repurchasing shares. In South Africa the specific share repurchase type should be classified into three (and not two, as defined in the regulatory environment) types, namely pro rata offers and two types of specific offers: the repurchase by the holding company of treasury shares held by subsidiaries and other specific offers (Bester et al., 2010). The types of entities which may repurchase shares in South Africa (namely the holding company, its subsidiaries and its share trusts) should be classified in terms of three main categories: holding companies repurchasing their shares from parties over which the holding company has no control; holding companies repurchasing their shares from parties over which the holding company has control (i.e. subsidiaries and share trusts); and holding company shares repurchased by parties over which the holding company has control (i.e. subsidiaries and share trusts). Five repurchasing entities are therefore relevant: the holding company repurchasing shares from parties over which the holding company has no control; the holding company repurchasing treasury shares from subsidiaries; the holding company repurchasing treasury shares from consolidated share trusts; subsidiaries repurchasing shares in the holding company; and consolidated share trusts repurchasing shares in the holding company.

\section{Dividend payments}

Similar dividend types are generally applied globally. The frequency of the dividend payments, however, differs between countries and companies. For the purpose of this study, scrip dividends were excluded from the definition of a dividend, because a scrip dividend does not represent a cash payment.

A company may utilise profits or share premium when paying dividends. Dividends are classified as either normal (regular) or special. Special dividends are paid over and above the normal dividend payments and are described as such by the company when announcing the payment thereof to emphasise the fact that they are infrequent payments.

In many countries dividends are generally paid on a quarterly basis. In South Africa companies generally make two dividend payments per annum, an interim and a final dividend. Final dividends are usually declared subsequent to the end of the reporting period of the company, based on the published results (which are only available subsequent to the end of the reporting period).

As stated in the section on share repurchases, the South African tax treatment of dividends differed from global practice during the period covered in this study: STC was levied on the dividend distribution, as opposed to the global practice of a withholding tax on dividends. As from 1 April 2012, the South African STC legislation was replaced with a withholding tax system.

\section{Share repurchase and dividend payout behaviour}

The increased popularity of share repurchases as part of companies' payout policies is well documented in global research. This dramatic increase in share repurchase activities raised the question whether share repurchases were substituting cash dividends.

When looking at global trends pertaining to the period covered in this study, they show that corporate share repurchases grew strongly as a popular means of returning cash to shareholders first in the USA, then the UK, and later - in the 1990s - in the continental European countries (Stonham, 2002: 37). From 1980 to 2006 the corporate use of share repurchases in the USA fluctuated in proximity to a general upward trend line, with a remarkable surge starting from 2004 (Dittmar, 2008: 27). Grullon and Michaely (2002: 1649 ) found that share repurchases grew at an average annual rate of 26,1 per cent over the period 1980 to 2000, whereas dividends grew at an average annual rate of only 6,8 per cent. The annual aggregate volume of repurchases by companies, excluding financials and utilities, listed on Compustat equalled dividends for the first time in 1998; surpassed dividends in 2005; and the margin of share repurchases over dividends widened significantly since 2006 (Dittmar, 2008: 27). In 2007 USA companies spent almost one trillion dollars on share repurchases, which was a record amount - which again exceeded dividend payments (Griffin \& Zhu, 2010: 1). Despite the deteriorating economic conditions experienced in 2009, the share repurchase figure of Standard \& Poor's (S\&P) 500 companies shot up to $\$ 230$ billion in the first quarter of 2010 from $\$ 75$ billion in the previous year (Dow Theory Forecasts, 2009: 3; Steverman, 2009: 1). In Europe largescale share repurchases started much later than in the USA, but grew even more rapidly since 1994. UK companies accounted for almost exactly half of the value of share repurchases by European Union (EU) companies for the period 1989 to 2005 (Von Eije \& Megginson, 2008: 355).

Dividend payment behaviour has shown a decrease in the percentage of companies paying cash dividends (Fama \& French, 2001: 39), but a real increase in the value of dividend payments was still reported (DeAngelo, DeAngelo \& Skinner, 2004; Dittmar, 2000: 349; Skinner, 2008; Von Eije $\&$ Megginson, 2008). The practice of a few large, dividendpaying companies paying even larger dividends, while companies paying small dividends stopped paying dividends altogether, was observed (DeAngelo et al., 2004). When comparing the different types of dividend payments over time in the USA, it was found that there had been a dramatic overall decline in the number of companies paying special dividends, as well as a decrease in the value of special dividends paid (as a percentage of total dividends paid) (DeAngelo, DeAngelo \& Skinner, 2000).

When comparing the share repurchase and dividend payment behaviour of USA industrials, Skinner (2008) found that few companies paid dividends without also making share repurchases. Payout was dominated by a relatively small group of companies which regularly repurchased shares and 
paid dividends every year (representing in number of companies an increase from 4,3 per cent during the period 1980 until 1989 to 4,8 per cent during the period 1995 until 2004; and based on the fraction of total payout represented an increase from 30,4 per cent to 61,6 per cent over this period) (Skinner, 2008: 587). Dividend and share repurchase policies of EU companies were found to be similar in many ways to USA companies (Von Eije \& Megginson, 2008). The total value of share repurchases also surged in Europe and accounted for half of total cash payouts in 2005 (Von Eije \& Megginson, 2008).

\section{Research population and research methodology}

\section{Research population}

The following JSE-listed companies comprised the population for the reporting periods including 1 July 1999 to the 2009 year-ends of the companies:

- Companies with listed ordinary and/or N-class shares;

- Companies with the JSE as their primary listing;

- Companies listed on the main board of the JSE, except for companies listed in the Basic Materials and Financials sectors; and

- Companies with at least three years of available data.

Odd lot offers were not treated as share repurchases as they had existed prior to 1999 . The research population comprised a total of 227 companies, including 87 companies which were delisted during the period.

\section{Research methodology}

For the purpose of this study, share repurchase data per reporting period per company were required on the following: number of shares repurchased; rand value of shares repurchased; repurchasing entity (i.e. the holding company repurchasing shares from parties it does not control or the holding company repurchasing shares from its subsidiaries and consolidated share trusts or subsidiaries repurchasing shares in the holding company or a consolidated share trust repurchasing shares in the holding company); type of repurchase (i.e. open market or specific repurchase, as well as a distinction between the types of specific repurchases pro rata offers, the repurchase of treasury shares by the holding company and other specific offers); and whether the share repurchase had been announced via SENS or not. Dividend data per reporting period per company were required on the rand value of the type of dividend paid (i.e. dividends paid from profits or dividends paid from share premium or special dividends paid).

The research method primarily entailed the collection of data from annual reports and also from the McGregor BFA database.

\section{Share repurchases}

Three steps were followed to ensure that share repurchase data were reliable and comprehensive. Firstly, each company included in the population was searched via SENS (as obtained from McGregor BFA: product called News) under each of the following keywords: 'repurchase', 'buy-back', 'buyback', 'buy back' and 'treasury' to obtain details on announced share repurchases.

Secondly, the annual report of each company included in the population was retrieved for each reporting period during the target period for which the company was listed. Hard copies of annual reports were predominantly used and, if not available from companies, electronic annual reports were retrieved via McGregor BFA (product called Library) or the internet. The annual reports of the 227 companies included in the population during the target period comprised a total of 1827 . Share repurchase activities were not always disclosed in a standardised format in annual reports during the target period. The directors' report, balance sheet (or statement of financial position), cash flow statement, statement of changes in equity, share capital note, and shareholders' analysis (or shareholder spread) were predominantly used to obtain details on share repurchase activity.

Thirdly, the information which was obtained via the two data collection methods was compared to ensure that no share repurchases were omitted; to identify which announcements led to actual share repurchases; to finalise the allocation of rand values and number of shares to different types of share repurchases and types of repurchasing entities; and to identify the unannounced share repurchases. Open market share repurchases which were announced subsequent to the actual repurchase date (owing to the application of the three per cent announcement rule) were allocated to the reporting period in which the actual repurchase was made in order to obtain the announced and unannounced components. For delisted companies, share repurchases announced before delisting, but subsequent to the final published annual report, were included in the share repurchase dataset only if the share repurchase could be verified as a cancellation in the number of issued shares on the McGregor BFA database (product called Price Data).

\section{Dividend payments}

Dividend data were compiled by scrutinising the annual reports to obtain information on dividends paid from profits and share premium. Adjustments to disclosed dividend data per annum were necessary to ensure that dividend data reflected dividends paid in cash, because IFRS requirements changed from an accrual basis to a cash (or dividend declaration date) basis in respect of reporting periods beginning on/after 1 October 2005 (SAICA, 2009). The McGregor BFA database (product called Financial Statements) could not be used to compile the dividend data, because McGregor BFA publishes dividends on the accrual basis. The McGregor BFA database (product called News, as well as Dividend History) was searched to capture details on 
special dividends declared and these were compared to annual report disclosures (to rectify errors in the McGregor BFA database in respect of dividends paid from share capital which were erroneously classified as special dividends). The rand amount of each special dividend declared was calculated by multiplying the dividend per share (as obtained from McGregor BFA: product called Dividend History or News, or annual report disclosures) with the number of shares on record date (as obtained from McGregor BFA: product called Price Data).

\section{Limitations of the study}

All the necessary measures were applied in establishing a reliable database on share repurchases and dividends. The data collection methods applied in this study required various calculations and reconciliations to compile reliable share repurchase data, because annual report disclosures were not always consistent and comprehensive - especially in respect of disclosures on treasury shares.

Share trust repurchase activity could, however, not be split between repurchases and sales (only a net annual movement in number could be calculated), as there was inadequate reporting thereof in annual reports and because share trust repurchases are not required to be announced via SENS. In this study share trust repurchases were therefore not included in the share repurchase data, and the repurchases by the holding company of shares held by the share trust were treated as repurchases from parties not controlled by the holding company.

\section{Results}

This study found that the first share repurchases only occurred in the reporting periods ending in 2000 in respect of the companies included in this study. All reported results therefore reflect 10 years, i.e. 2000 to 2009.

\section{Share repurchases}

When reporting the results on share repurchases, the impact of the aspects unique to the South African share repurchase environment firstly needed to be ascertained. The effect of subsidiaries repurchasing shares in the holding company (and the subsequent sale thereof to the holding company), as well as the three per cent announcement rule on open market share repurchases, was especially relevant.

This study found that 115 (or 50,66 per cent) of the 227 companies included in the population repurchased shares in the reporting periods including 1 July 1999 to the 2009 yearends of the companies. The total value of share repurchases comprised R136,89 billion over the target period. The favoured entity through which share repurchases were conducted was subsidiaries, representing 40,29 per cent of the total share repurchase value. Share repurchases by the holding company of treasury shares held by subsidiaries comprised 31,35 per cent of share repurchase value and share repurchases by the holding company from parties which it did not control represented 28,36 per cent of share repurchase value. Based on number of shares it was found that about 46 per cent of the number of shares initially repurchased by subsidiaries was subsequently sold to the holding company.

By allowing subsidiaries to repurchase shares in the holding company (along with the favourable tax treatment thereof) affected not only the types of entities entering into share repurchases, but also the value attributable to the different types of share repurchases. It was found that open market share repurchases were not the favoured share repurchase type, as is the case globally. Open market share repurchases comprised 42,56 per cent of total share repurchase activity over the target period. The repurchase by the holding company of the treasury shares held by subsidiaries was the favoured specific share repurchase type (comprising 54,54 per cent of total specific share repurchase value), while other specific offers and pro rata offers comprised 32,56 per cent and 12,86 per cent of total specific share repurchase value, respectively.

This study found that, owing to the three per cent announcement rule on open market share repurchases, only 58,72 per cent of open market share repurchase value was announced via SENS during the target period. These announcements, however, did not reflect actual-time-based information, because the announcements referred to share repurchases made in the previous year(s)/months(s)/weeks(s) and on the previous day, depending on how the rule was interpreted and when the limit was reached. It was also found that all specific share repurchases were not announced via SENS. Unannounced specific share repurchases mainly comprised the repurchase by the holding company of treasury shares held by subsidiaries. It seemed that companies did not recognise the repurchase of treasury shares by the holding company as a specific repurchase type, but merely saw it as an internal group transaction.

The unique South African regulatory environment therefore resulted in the South African experience not mirroring global practice in respect of the types of entities repurchasing shares; the popularity of the open market share repurchase type; and the availability of comprehensive and actual-time-based information.

Share repurchases were allowed only as from 1 July 1999 and it therefore needed to be ascertained what the trend in share repurchases was over the first 11 years since the practice was allowed. Figure 1 shows the share repurchase activity per annum (based on deflated figures) for the target period. A distinction is made between total share repurchase activity and share repurchase activity excluding the repurchase of treasury shares by the holding company. Share repurchase activity excluding the repurchase of treasury shares represents the cash effect of share repurchases (because the repurchase of treasury shares by the holding company has a net nil effect in the consolidated annual report) and generally resembles global practice on the definition of share repurchase activity. 
Figure 1 shows that total share repurchase activity started off slowly, decreased in 2003 and 2004, and became popular from 2005. Total share repurchase activity increased from 2005 to 2007, decreased slightly in 2008 and showed a steady increase in 2009 (with a value in excess of the 2007 share repurchase levels). Share repurchases excluding the repurchases of treasury shares by the holding company showed a similar trend to total share repurchase activity until 2006, but in 2007 there was a decrease, while 2008 showed a large increase, and a steady increase was again observed in 2009. The decrease in share repurchase activities excluding the repurchases of treasury shares by the holding company in 2007 was expected in response to the global financial crisis in $2007 / 2008$.

When evaluating the trend in the total share repurchase activity as opposed to the share repurchases excluding the repurchases of treasury shares by the holding company (as may be observed in Figure 1), it is evident that the repurchase of treasury shares by holding companies contributed greatly to total share repurchase activities in 2007, but not in 2008 . In this study it was found that subsidiaries were the preferred share repurchase entity until 2006, which may have necessitated that holding companies repurchase treasury shares from 2005 to 2007 (because of the 10 per cent limit imposed on subsidiaries). Subsidiary repurchases were again at high levels in 2008 and dropped dramatically in 2009, while the high increase in holding company repurchasing of treasury shares in 2009 may be in response to the high subsidiary repurchases in 2008. The drop in the 2008 figure of treasury shares repurchased by the holding company cannot necessarily be related to the STC payable period starting on 1 October 2007. The payment of STC on the repurchase of treasury shares by the holding company affected only those companies with reporting periods ending subsequent to 30 September 2008. In a study by Wesson and Hamman (2012) it was found that repurchases of treasury shares by holding companies still occurred subsequent to the negative income tax treatment thereof.

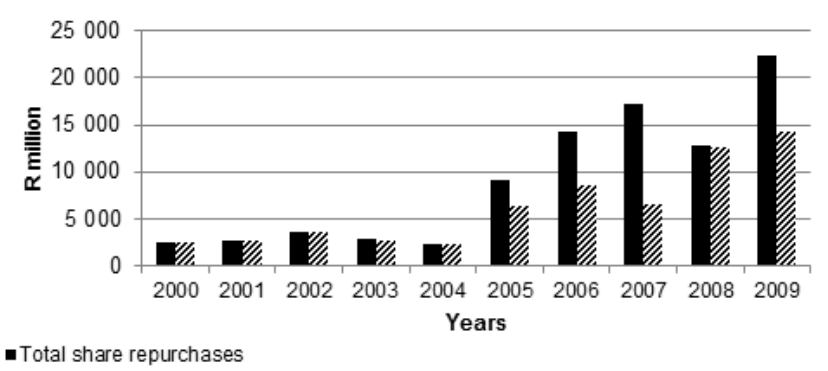

थShare repurchases excluding the repurchase of treasury shares by the holding company

Figure 1: Share repurchase activity (adjusted to reflect 1999 prices)

A better understanding of the South African share repurchase experience was obtained by analysing the number and size of the companies involved in share repurchases per annum, as well as the annual rand amounts spent by these companies. Table 1 contains the descriptive statistics on share repurchase value per annum over the target period. The large standard deviation, as well as the maximum, indicates that a small number of companies contributed most to the share repurchase value per annum.

Table 1: Descriptive statistics on annual share repurchases

\begin{tabular}{r|r|r|r|r|r|r}
\hline Year & \multicolumn{1}{|c|}{ Mean } & \multicolumn{1}{c|}{ Median } & \multicolumn{1}{c|}{ Minimum } & \multicolumn{1}{c|}{ Maximum } & Standard deviation & Standard deviation \% \\
\hline 2000 & 167603030 & 15441578 & 1826000 & 1290000000 & 356344503 & $212.61 \%$ \\
\hline 2001 & 80270028 & 13920000 & 166000 & 111900000 & 197341235 & $245.85 \%$ \\
\hline 2002 & 93966314 & 17814000 & 56981 & 1020000000 & 203006128 & $216.04 \%$ \\
\hline 2003 & 67606538 & 14508000 & 7000 & 704000000 & 142656958 & \\
\hline 2004 & 73459987 & 13012500 & 102920 & 476600000 & 111678016 & \\
\hline 2005 & 304575153 & 32953000 & 2768 & 2916000000 & 618667416 & $152.03 \%$ \\
\hline 2006 & 529183258 & 37673000 & 1 & 5512000000 & 1307978508 & $203.12 \%$ \\
\hline 2007 & 889810682 & 36197000 & 44000 & 17975000000 & 3324548262 & $247.17 \%$ \\
\hline 2008 & 541480593 & 123157500 & 4000 & 7300000000 & 1305180429 & $373.62 \%$ \\
\hline 2009 & 1227271496 & 18411000 & 30425 & 21226000000 & 3958641795 & \\
\hline
\end{tabular}

Figure 2 makes a distinction in total share repurchase value per annum in terms of small, medium and large companies. The company size was obtained by comparing the actual market capitalisation of the company at the end of the reporting period in which the share repurchase was made to a small/medium/large norm based on market capitalisation. The small/medium/large norm was calculated by ranking all companies listed on the JSE All Share Index (usually about 160 companies) as at the end of June for each of the years covered in the study, in ascending order of market capitalisation. The small/medium/large classification was obtained by identifying the first third of market capitalisations on the list as small companies; the next third as medium; and the final third as large. From Figure 2 it may be observed that share repurchase value per annum was dominated by companies with large market capitalisations. 


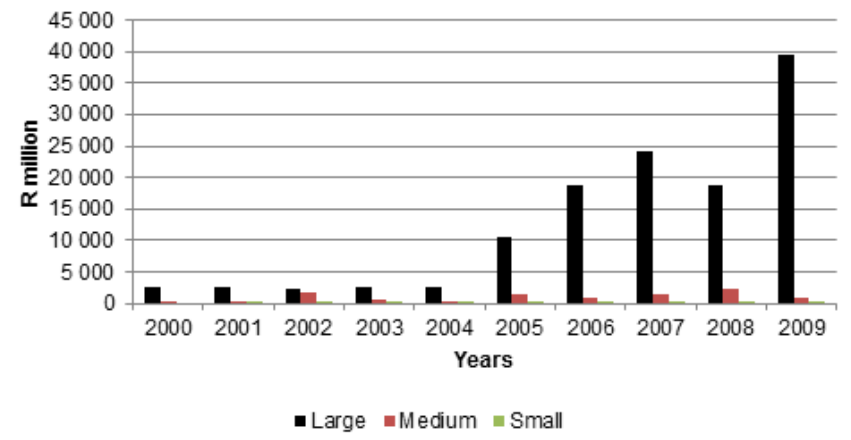

Figure 2: Share repurchase value based on market capitalisation

Figure 3 however shows that, based on number of companies per annum, it was mostly small companies that entered into share repurchases over the target period. Although small companies did not dominate the first two years of repurchase activity (based on number of companies), this group dominated all other years, except 2004 to 2006, where this group equalled the number of large capitalisation companies entering into share repurchases. More small companies therefore repurchased shares, but the value of share repurchases was dominated by companies with large market capitalisations (as may be observed in Figure 2).

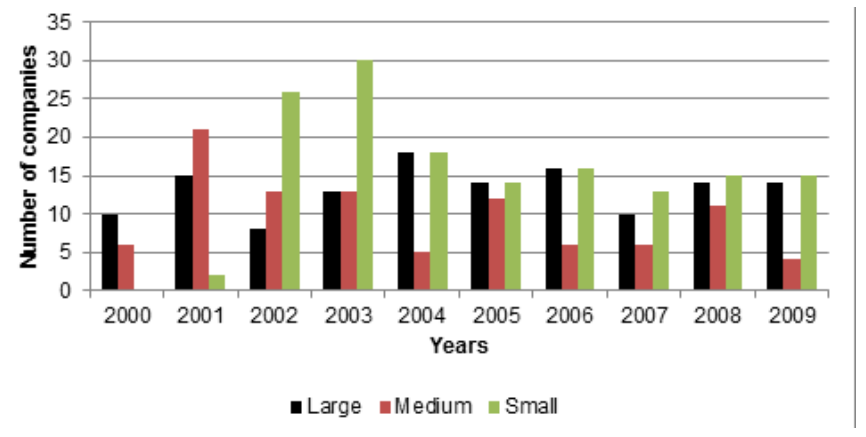

Figure 3: Number of companies repurchasing shares based on market capitalisation

The results of Table 1, Figure 2 and Figure 3 were confirmed when further analysis of the share repurchase data was done. It was found that more than 50 per cent of the total share repurchase value was contributed by only four companies. Two companies contributed more than 40 per cent (in total) towards the share repurchase activity during the target period:
Sasol Ltd made share repurchases to the value of R38 billion (representing about 28 per cent of total share repurchase value) and MTN Group Ltd made repurchases to the value of R21 billion (representing about 16 per cent of total share repurchase value). Remgro Ltd and Netcare Ltd each contributed more than five per cent towards the total share repurchase value. These four companies are all large market capitalisation companies.

\section{Dividend payments}

This study found that 178 (or 78,41 per cent) of the 227 companies included in the population spent R247,15 billion on dividends during their 2000 to 2009 reporting periods. Dividends paid from profits were the favoured dividend type during the target period, representing 75,39 per cent of total dividend payment value. Special dividends and dividends paid from share premium represented a small proportion of total dividend payment value, attributing to 13,40 per cent and 11,21 per cent, respectively.

Global empirical evidence shows that the number of companies paying dividends has decreased over time, but that the real value of dividend payments still showed an increase. This study found that the number of dividend-paying companies increased from 58,74 per cent in 2000 to 75,00 per cent in 2009. The compound annual growth rate for dividend payments (based on deflated figures) was 18,8 per cent during the target period. South African dividend payment behaviour therefore did not fully mirror global practice.

Global practice on special dividends was also not fully mirrored in South Africa. The value of special dividends declined, as a percentage of total dividends paid, from 9,03 per cent in 2000 to 7,33 per cent in 2009. Based on number of companies, however, the companies paying special dividends increased from 2,43 per cent in 2000 to 6,43 per cent in 2009.

Table 2 contains the descriptive statistics on dividend payment value per annum over the target period. Dividend payments show a high standard deviation percentage, indicating that large payments were made by a few companies. Further analysis of dividend payment behaviour is discussed in the section below, which deals with share repurchase and dividend payout behaviour. 
Table 2: Descriptive statistics on annual dividend payments

\begin{tabular}{r|r|r|r|r|r|r}
\hline Year & Mean & Median & \multicolumn{1}{c|}{ Minimum } & Maximum & Standard deviation & Standard deviation \% \\
\hline 2000 & 49383981 & 13270000 & 534000 & 301900000 & 83641858 & $169.37 \%$ \\
\hline 2001 & 51905575 & 13336000 & 78000 & 1025000000 & 122408374 & \\
\hline 2002 & 65762282 & 17087000 & 400000 & 1763000000 & 181768950 & $235.83 \%$ \\
\hline 2003 & 108795355 & 29983000 & 500000 & 2530000000 & 287253234 & $276.40 \%$ \\
\hline 2004 & 128119948 & 29437500 & 1292000 & 3107000000 & 346778891 & $264.03 \%$ \\
\hline 2005 & 161776626 & 39329000 & 660000 & 3014000000 & 366564151 & $270.67 \%$ \\
\hline 2006 & 199619232 & 50263500 & 500000 & 3135000000 & 431021225 & $226.59 \%$ \\
\hline 2007 & 311995271 & 76187000 & 37000 & 5014000000 & 764858139 & $215.92 \%$ \\
\hline 2008 & 323007795 & 65504353 & 627000 & 4885000000 & 765444539 & \\
\hline 2009 & 344706500 & 82160000 & 1594000 & 6020000000 & 843633290 & $245.15 \%$ \\
\hline
\end{tabular}

\section{Share repurchase and dividend payout behaviour}

Share repurchases were allowed much later in South Africa compared to countries like the USA and the UK, where the global precedent has been set. It cannot reasonably be expected that share repurchases would exceed dividend payments within the first 11 years of being allowed in South Africa. When comparing total share repurchase value to total dividends paid, the total distribution of R384,04 billion (i.e. share repurchases of R136,89 billion and dividends paid of R247,15 billion) was mainly attributed to dividends, representing 64,35 per cent of the total distribution. When comparing the share repurchases actually paid in cash from a group perspective (thus excluding the treasury shares repurchased by the holding company), the total distribution was R341,12 billion of which 27,55 per cent was spent on share repurchases and 72,45 on dividends paid.

The number of companies involved in share repurchases increased from 7,77 per cent in 2000 to 23,57 per cent in 2009 , whereas the number of companies paying dividends increased from 58,74 per cent in 2000 to 75,00 per cent in 2009. Total share repurchases (based on deflated figures) showed a general upward trend, with a compound annual growth rate of 27,32 per cent over the target period. The compound annual growth rate of share repurchases excluding the treasury shares repurchased by the holding company (based on deflated figures) was 28,64 per cent over the target period. Dividends paid (based on deflated figures) also showed a general upward trend, with a compound annual growth rate of 18,8 per cent over the target period. The South African experience therefore mirrored global practice in that share repurchase growth exceeded the dividend growth during the target period.

Figure 4 shows the rand values, adjusted to reflect 1999 prices, of total dividends paid and share repurchases per annum. For the purpose of this analysis the share repurchases excluding the treasury shares repurchased by the holding company were used when referring to share repurchases, because this figure represents the cash effect for the group and also because the effect of the repurchase of treasury shares by the holding company on total share repurchases has already been explained in Figure 1. Share repurchases became popular as from 2005. It appears that the negative economic conditions in 2007/2008 had a larger effect on dividends than on share repurchases: both dividends and total share repurchases showed a decrease in 2007, but in 2008 share repurchases increased as opposed to decreased, as is shown in the dividend payment value. In 2008 and 2009 share repurchases amounted to about 50 per cent of the dividend value (based on deflated figures). It may therefore be concluded that share repurchases had become an important payout method in the final two years of this study.

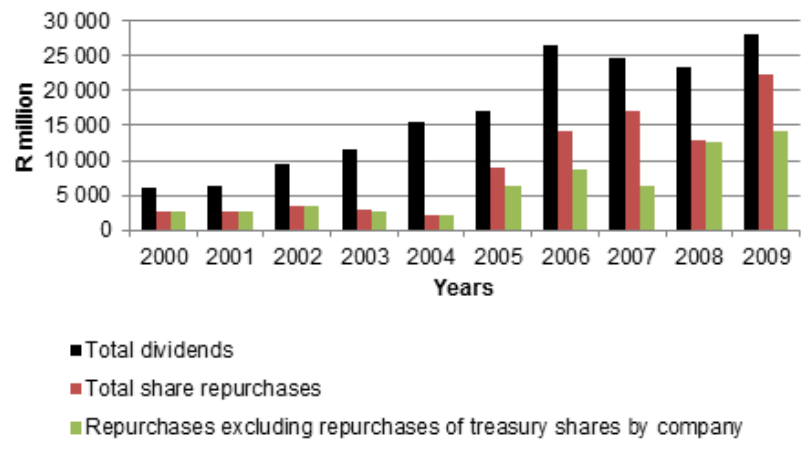

Figure 4: Share repurchases versus dividends based on value (adjusted to reflect 1999 prices)

Figures 5 and 6 compare the different payout behaviours of companies over the target period. Of the 227 companies included in this study, 12 (or 5,29 per cent) only repurchased shares, and did not pay dividends; 75 (or 33,04 per cent) only paid dividends, and did not repurchase shares; 103 (or 45,37 per cent) paid dividends and made share repurchases; and 37 (or 16,30 per cent) neither paid dividends nor made share repurchases over the target period. The 103 companies which paid dividends and repurchased shares during the target period could be divided into two categories (as may be observed in Figure 5): those who paid dividends every year and regularly (i.e. during 50 per cent or more of the reporting periods in which the company was listed) repurchased shares, and those who paid dividends (but not every year) and irregularly (i.e. during less than 50 per cent of the reporting periods in which the company was listed) repurchased shares. These two categories represented 22 (or 9,69 per cent) and 81 (or 35,68 per cent) companies, respectively, over the target period.

Figure 6 shows that payout behaviour based on total payout differs from payout behaviour based on number of companies (as may be observed in Figure 5). Total payout is defined as 
total share repurchase value plus total dividends paid. A small number of companies (only 9,69 per cent) which always paid dividends and regularly repurchased shares contributed to the greater proportion of payout (i.e. 46,92 per cent) over the target period. The share repurchase behaviour reported in this study therefore mirrors global experience.

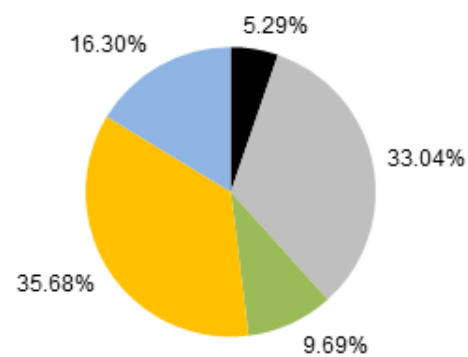

- Only repurchased shares

- Only paid dividends

- Repurchased shares regularly and paid dividends every year

= Repurchased shares irregularly and paid dividends (but not every year)

- No repurchase of shares, no dividends paid

Figure 5: Payout behaviour based on number of companies

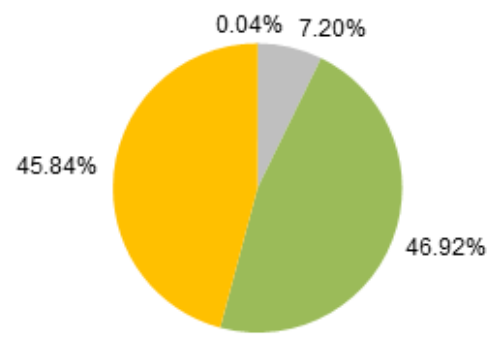

- Only repurchased shares

m Only paid dividends

m Repurchased shares regularly and paid dividends every year

= Repurchased shares irregularly and paid dividends (but not every year)

Figure 6: Payout behaviour based on value

\section{Conclusion}

Share repurchases are becoming the favoured payout method, when compared with dividend payments. The increasing use of share repurchases has triggered renewed concern over what the actual motivation for these share repurchases is and whether investments to ensure future growth are now being forfeited in favour of share repurchases. Global empirical evidence exists on share repurchase and dividend payout behaviour. Comprehensive data on South African share repurchases, however, do not exist. In this study the first comprehensive database on share repurchases, as well as dividends, was compiled for companies in selected JSE-listed sectors for the first 11 years (i.e. 1999 to 2009) since share repurchases were allowed in South Africa. The purpose of the study was to ascertain whether share repurchase and dividend payout behaviour by JSE-listed companies mirrored current global empirical evidence.
This study found that share repurchases by JSE-listed companies have become popular since 2005 and that the most recent years of the study (2008 and 2009) showed a sharp increase in the value of share repurchases. Dividends were still the preferred payout method, but showed a lower growth rate than share repurchases over the target period of the study. Total payout was found to be dominated by a few companies paying dividends every year and regularly repurchasing shares.

Aspects unique to the South African regulatory environment affected the results of the study. The popularity of share repurchases being conducted via subsidiaries (and the subsequent sale of these treasury shares to the holding company) resulted in open market share repurchases not being the outright favourite share repurchase type, as is the case globally. The three per cent announcement rule on open market share repurchases led to share repurchase data (as announced via SENS) not representing comprehensive and actual-time-based data. The unique South African regulatory environment also affected the annual report disclosures on share repurchases and the application of the SENS announcement rules by companies repurchasing shares.

The South African regulatory environment needs to be brought into alignment with certain of the best practices followed in developed countries to ensure that accurate and complete information on share repurchases is readily available to all stakeholders affected by share repurchase transactions. The current three per cent announcement rule on open market share repurchases should be replaced with a daily announcement rule applicable to share repurchases by all repurchasing entities (therefore including subsidiary repurchases and also repurchases by share trusts). The format of SENS announcements on open market and specific repurchases needs to be standardised to ensure that share repurchasing entities and share repurchase types are comprehensively and consistently reported. Specific guidance is also required on the application of IFRS in the South African share repurchase environment. The monitoring of the compliance to the SENS announcement requirements, as well as the application of IFRS in the South African regulatory environment, should be a priority of the relevant regulatory bodies.

Although South Africa is a developing country and an emerging economy, this study found that certain aspects of the South African share repurchase and dividend payout behaviour did mirror the recent global empirical evidence. Certain aspects of the South African regulatory environment, however, resemble the financial systems of a developing country and need to be aligned to those of developed economies to meet the informational needs of all stakeholders.

With the data on South African share repurchase and dividends now being visible for the first time, it is evident that share repurchases are also a popular payout method in South Africa - as is the case globally. Future research should extend the research period of this study and should address the motivation for share repurchases, as well as the effect of share 
repurchases on capital expenditure (i.e. investments for future growth). Research on share repurchases is vital as economic growth is a critical aspect in the global and especially the South African economy. Economies cannot afford share repurchases to erode future economic growth.

\section{References}

Barnes, M. 2015. Straight talk: Share buybacks defy all logic. [Online] Available: http://www.bdlive.co.za/opinion/columnist/ 2015/05/04/straight-talk-share-buybacks-defy-all-logic Accessed: 4 May 2015.

Bester, P.G., Wesson, N. \& Hamman, W.D. 2010. 'Share buy-backs for a selection of JSE-listed companies: An exploratory study', South African Journal of Business Management, 41(4), 47-58.

Brennan, D.M. 2007. Co-opting the shareholder value movement: A class analytic model of share repurchases. Paper presented at the International Studies Association Annual Meeting. Lancaster: Conference Papers, 1-37.

Cassim, F.H.I. 2003. 'The repurchase by a company of its own shares: The concept of treasury shares', Stellenbosch Law Review, 120(1), 137-152.

Crotty, A. 2012. Share buy-backs ban moved to a virtual-free-forall. Business Report, 21 June. [Online] Available: http://www.iol.co.za/business/business-news/share-buy-backs-banmoved-to-a-virtual-free-for-all Accessed: 27 June 2012.

DeAngelo, H., DeAngelo, L. \& Skinner, D.J. 2000. 'Special dividends and the evolution of dividend signaling', Journal of Financial Economics, 57(3), 309-354.

DeAngelo, H., DeAngelo, L. \& Skinner, D.J. 2004. 'Are dividends disappearing? Dividend concentration and the consolidation of earnings', Journal of Financial Economics, 72(3), 425-456.

Dittmar, A.K. 2000. 'Why do firms repurchase stocks?', Journal of Business, 73(3), 331-356.

Dittmar, A.K. 2008. 'Corporate cash policy and how to manage it with stock repurchases', Journal of Applied Corporate Finance, 20(3), 22-34.

Dow Theory Forecasts. 2009. Companies buy back fewer shares. $\mathbf{6 5}(25), 22$ June, 3-5.

Fairchild, R. \& Zhang, G. 2005. Repurchase and dividend catering, managerial myopia, and long-run value destructions. Working paper series, 2005-21. Bath: University of Bath School of Management.

Fama, E.F. \& French, K.R. 2001. 'Disappearing dividends: Changing firm characteristics or lower propensity to pay?', Journal of Financial Economics, 60(1), 3-43.

Ginglinger, E. \& Hamon, J. 2007. 'Actual share repurchases, timing and liquidity', Journal of Banking \& Finance, 31(3), 915-938.

Griffin, P.A. \& Zhu, N. 2010. 'Accounting rules? Stock buybacks and stock options: Additional evidence', Journal of Contemporary Accounting \& Economics, 6(1), 1-17.
Grullon, G. \& Michaely, R. 2002. 'Dividends, share repurchases, and the substitution hypothesis', Journal of Finance, 57(4), 16491684 .

Grullon, G. \& Michaely, R. 2004. 'The information content of share repurchases programmes', Journal of Finance, 59(2), 651-680.

Ikenberry, D., Lakonishok, J. \& Vermaelen, T. 1995. 'Market underreaction to open market share repurchases', Journal of Financial Economics, 39(2-3), 181-208.

JSE. 2007. JSE Listings Requirements. Service issue no. 3. Johannesburg: LexisNexis Butterworths. [Online] Available: http://www.jse.co.za/listing_requirements.jse Accessed: 10 April 2013.

JSE. 2013. JSE Listings Requirements. Service issue no. 16. Johannesburg: LexisNexis Butterworths. [Online] Available: http://www.jse.co.za/How-To-List/Listing-requirements/JSElisting-requirements.aspx Accessed: 10 July 2013.

Kim, J., Schremper, R. \& Varaiya, N. 2004. Survey on open market repurchase regulations: Cross country examination of the ten largest stock markets. Working paper. San Diego State: Centre for International Business Education and Research.

Kobokoane, N. 2007. Share buybacks in South Africa: An empirical investigation. Unpublished MBA research report. Bellville: University of Stellenbosch.

Lazonick, M. 2014. 'Profits without prosperity', Harvard Business Review, September, 47-55.

Manconi, A., Peyer, U. \& Vermaelen, T. 2013. Buybacks around the world. Faculty and research working paper. Fontainebleau: INSEAD.

Mitchell, J.D. \& Dharmawan, G.V. 2007. 'Incentives for on-market buy-backs: Evidence from a transparent buy-back regime', Journal of Corporate Finance, 13(1), 146-169.

RSA (Republic of South Africa). 1999. Companies Amendment Act, no. 37 of 1999. Pretoria: Government Printer.

RSA (Republic of South Africa). 2008. Companies Act, no. 71 of 2008. Pretoria: Government Printer.

SAICA (South African Institute of Chartered Accountants). 2009. Events after the reporting period. IAS 10. Updated: June. Pietermaritzburg: Interpak Books.

Skinner, D.J. 2008. 'The evolving relation between earnings, dividends and stock repurchases', Journal of Financial Economics, 87(3), 582-609.

Steverman, B. 2009. The incredible shrinking stock buy backs. Business Week, 19 June. [Online] Available: http//www.businessweek.com.ez.sun.ac.za/investor/content/ jun2009/pi20090618_506017.htm Accessed: 10 September 2009.

Stonham, P. 2002. ‘A game plan for share repurchases', European Management Journal, 20(1), 37-44.

Von Eije, H. \& Megginson, W.L. 2008. 'Dividends and share repurchases in the European Union', Journal of Financial Economics, 89(2), 347-374. 
Wesson, N. \& Hamman, W.D. 2011. 'Disclosure of share capital: Are reporting standards clear?', Accountancy SA, February, 32-34.

Wesson, N. \& Hamman, W.D. 2012. 'The repurchase by a holding company of treasury shares held by subsidiaries: A South African perspective', South African Journal of Business Management, 43(4), $33-44$.

Wesson, N. \& Hamman, W.D. 2013. 'Inconsistent shareholder spread disclosures', Accountancy SA, February, 20-21. 